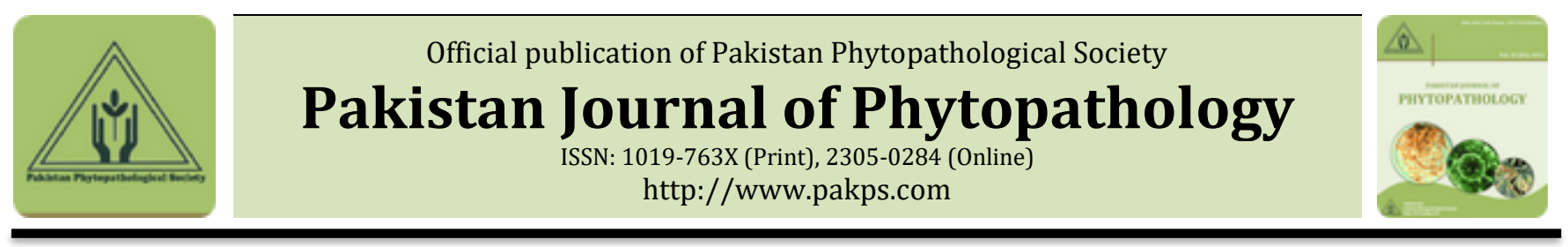

\title{
TWO NEW NEMATODE SPECIES FROM PISTACHIO FAUNA IN KHORASAN RAZAVI PROVINCE OF IRAN
}

\author{
aReyhane Hadadfar*, aEsmat M. Moghadam, aSareh Baghaee, a,b Majid S. Bajestani \\ a Department of Plant Protection, Faculty of Agriculture, Ferdowsi University of Mashhad, Iran. \\ ${ }^{b}$ Educational management office, Ferdowsi University of Mashhad, Iran.
}

\begin{abstract}
A B S T R A C T
Pistachio is an important nut crop in Iranian horticulture which is a strategic and valuable export product and holds the first position in non-oil export of Iran. So that Iran is the largest producer of pistachio that is the first exporter in world and Khorasan Razavi province as the second largest producer in the country has a special position in this regard. Considering that nematodes are one of the most important soil pathogenic agents and can cause considerable damage to pistachio in high populations, since the re are no studies on biodiversity of plant parasite nematodes in pistachio gardens of Khorasan Razavi province, so identification of Pistachio plant parasite nematodes is very important. To identify plant parasitic nematodes in pistachio fields of Khorasan Razavi province northeast of Iran, in the years 2016 and 2017 collected 70 root and soils samples from pistachio root rhizosphere (depth $30-50 \mathrm{~cm}$ ). Samples transferred to laboratory on ice and nematode were extracted by centrifugal and Whithead methods. After obtaining permanent microscopic slides from extracted nematodes, samples considered by $\mathrm{BH} 2$ Olympus microscope equipped with drawing tube. In this study 19 species belongs to 8 genus described as: Ditylenchus medicaginis, Pratylenchus neglectus, Pratylenchus coffeae, Pratylenchus wescolagricus, Psilenchus iranicus, Psilenchus hilarus, Psilenchus aestuarius, Psilenchus bilineatus, Psilenchus curcumerus, Psilenchus pratensis, Psilenchus bahiablancea Merlinius graminicola, Merlinius planitierus, Merlinius gatevi, Nagelus leptus, Geocenamus tessellatus, Geocenamus rugosus, Geocenamus koreanus, Meloidogyne javanica and Helichotelenchus exallus. Between this species Geocenamus koreanus and Merlinius gatevi described for first time from Iran nematode fauna and five species have been reported for the first time in Iran. In this study, Pratylenchus (root lesion nematodes) among the other species has the most abundance and dispersion, so they are important.
\end{abstract}

Keywords: Plant parasitic nematodes, Geocenamus koreanus, Merlinius gatevi, Pistachio

\section{INTRODUCTION}

Pistachio is one of the agricultural products that its name mixed with the name of Iran, according to the historical records for native land of Pistachio showed there was in northeast of Great Khorasan Provinces and Khaje Sarakhs forests in Khorasan Razavi province (Tavallali and Rahemi, 2007). Pistacia vera is a semi-tropical plant with two vegetative bases,

\footnotetext{
Submitted: July 11, 2020

Revised: September 03, 2020

Accepted for Publication: November 04, 2020

* Corresponding Author:

Email: r.hadadfar@ymail.com

(c) 2017 Pak. J. Phytopathol. All rights reserved.
}

which are found in the form of massive forests in northeastern Iran (Nakhaee nejad, 2007). Pistachio planting moved from Iran to other parts, especially to the Mediterranean coast (southern Europe and North Africa). Pistachio is a strategic product and has a special place in Iran's agricultural production, because of economic significance it known as a green gold. This product accounted about $55 \%$ of non-oil exports and more than $60 \%$ of global exports in Iran. The income from pistachio exports in Iran is over $\$ 400$ million for one year (Amuzegar Jahangir, 2003). The most important cultivars of this product in Iran are Akbari, Kaleh Qouchi, Ahmad Aghaei, Ohadi, Badami, Zarand Momtaz, Khanjari Damghan, Shahpasand, Sefid Qazvin (Amuzegar Jahangir, 2003). 
Currently, Iran's pistachio cultivation areas are more than 440 thousand hectares. Khorasan Razavi province is one of the important areas for pistachio planting in Iran and according to information released by the statistical Agriculture in 2015; more than $20 \%$ of the total country's pistachio production was in this province (Iranian statistical agriculture reports 2015). This plant has several diseases including, plant parasitic nematodes (Neshat, 2011). In Iran, only Susan Neshat et al. in 2011 surveyed pistachio nematode fauna in Rafsanjan Province of Iran and described 23 species belongs to 16 genus. They reported that genus Meloidogyne with a frequency of $40 \%$, genus Geocenamus with 33\% frequency, Pratylenchus genus with $31 \%$ frequency and Longidorus genus with $20 \%$ frequency had the highest percentage of distribution among other genus.

The genus Geocenamus was established by Thorne and Malek (1968) in the subfamily Tylenchoryhynchinae. The name of the genus is derived from a contraction of Geographic center of North America, reflecting the region from which it was first described. As of October 2003, the Zoological Record indicates 51 species names associated with this genus. The genus is distinguished from other genera within the subfamily by a labial disc. The cephalic framework is weak and the stylet slender.

In the genus Geocenamus, body has six lateral fields that in some species, in addition to the lateral fields, existence other longitudinal grooves witch along the entire surface of the skin that interrupts the transverse grooves and lattice appear to the skin surface. The stylet, elegant and slim to strong, length varies from 25 to 130 micrometers; stylet cone length is larger than the cylindrical portion. Tohren and Malik placed this genus in Tylenchorhynchidae family in 1968. Siddiqi placed this genus in Merlininae family and considered with 14 species.

The aim of this study was to complete investigate of pistachio parasitic nematodes in Khorasan Razavi province, because after the comprehensive identification of pathogenic nematodes, appropriate decisions can be made to control the damage caused by these pathogens. Since only, one study has been done in the Rafsanjan region on this product (Neshat et al., 2011), this study would be an appropriate option for research on Iranian nematode fauna.

\section{MATERIALS AND METHODS}

Soil sampling: Soil and root samples collected from the rhizospheres of Pistachio gardens of Khorasan Razavi provinces in East of Iran. Soil samples (70) were taken from the depth of $30-50 \mathrm{~cm}$ put in polyethylene bags with necessary labeled and brought to the laboratory and processed.

Processing of samples: Nematodes were extracted from soil samples by using the Jenkins (1964) and Whitehead and Hemming (1965) methods, killed and fixed according to De Grisse (1969). Genera and species were identified based on morphological and morphometric characters (Siddiqi, 2000; Geraert, 2008). Specimens were heat-killed by adding boiling 4\% formalin solution, and were then transferred to anhydrous glycerin according to De Grisse (1969). Measurements and drawings were performed using a drawing tube attached to an Olympus $\mathrm{BH} 2$ light microscope (LM). Morphometric abbreviations and ratios were used in the present study (Siddiqi, 2000). Nematodes were identified based on morphological and morphometric characteristics, using identification keys (Raski, 1975; Huang and Raski, 1987; Geraert, 2008).

Measurements and drawings: Measurements were taken with an ocular micrometer of "Olympus BH2" model microscope. Drawings were made with drawing tube attached to the compound microscope.

\section{RESULTS AND DISCUSSION}

In this study 19 species from 8 genus were identified viz. Ditylenchus medicaginis, Pratylenchus neglectus, Pratylenchus coffeae, Pratylenchus wescolagricus, Psilenchus iranicus, Psilenchus hilarus, Psilenchus aestuarius, Psilenchus bilineatus, Psilenchus curcumerus, Psilenchus pratensis, Psilenchus bahiablancea Merlinius graminicola, Merlinius planitierus, Merlinius gatevi, Nagelus leptus, Geocenamus tessellatus, Geocenamus rugosus, Geocenamus koreanus, Meloidogyne javanica and Helichotelenchus exallus (Table 1). Merlinius gatevi (Sturhan, 2012) (Figure 1, Table 2)

According to Sturhan's studies in 2012 Geocenamus gatevi was renamed to Merlinius gatevi. This renaming was based on Sturhan's observations, including presence of dirids, 4 to 6 lateral fields, presence of inner cuticle layer on tail, semi-cylindrical tail with sharp tip end, stylet with more than $30 \mu \mathrm{m}$ long and lack of longitudinal lines. This species was similar to those described by Budurova in the 1988 and Garrett in 2008. 
Table 1. List of nematode species from Pistachio garden in Khorasan Razavi province east of Iran with GPS pots, name of sampling areas, diagnostic key and first description in Iran.

\begin{tabular}{|c|c|c|c|c|c|}
\hline Number & species & Areas & UTM & Diagnostic key & $\begin{array}{l}\text { Firs description in } \\
\text { Iran }\end{array}$ \\
\hline 1 & $\begin{array}{l}\text { Ditylenchus } \\
\text { medicaginis }\end{array}$ & Feiz abad city & $\begin{array}{l}665020- \\
3878188\end{array}$ & Wasilewska, 1965 & 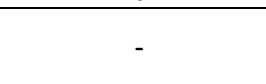 \\
\hline 2 & Merlinius gatevi** & Feiz Abad City & $\begin{array}{l}665031- \\
3878147\end{array}$ & (Budurova, 1988) Brzeski, 1991 & - \\
\hline 3 & $\begin{array}{l}\text { Geocenamus } \\
\text { koreanus** }\end{array}$ & $\begin{array}{l}\text { Kheir Abad } \\
\text { city }\end{array}$ & $\begin{array}{l}656790- \\
3873902\end{array}$ & $\begin{array}{c}\text { (Choi and Geraert, 1971) Brzeski, } \\
1991\end{array}$ & - \\
\hline 4 & Geocenamus rugosus & Feiz Abad City & $\begin{array}{l}665010- \\
3878142\end{array}$ & (Siddiqi,1963) Brzeski, 1991 & $\begin{array}{l}\text { Mojtahedi et al., } \\
1983\end{array}$ \\
\hline 5 & $\begin{array}{l}\text { Geocenamus } \\
\text { tessellatus }\end{array}$ & Taybad city & $\begin{array}{l}288946- \\
3848257\end{array}$ & (Goodey,1952) Brzeski 1991 & Baadl et al., 2012 \\
\hline 6 & $\begin{array}{l}\text { Helichotylenchus } \\
\text { insignis }\end{array}$ & $\begin{array}{l}\text { Bardaskan } \\
\text { City }\end{array}$ & $\begin{array}{l}594560- \\
3890373\end{array}$ & Sher, 1966 & Jabberi et al., 2008 \\
\hline 7 & Merlinius graminicola & $\begin{array}{l}\text { Kheir Abad } \\
\text { city }\end{array}$ & $\begin{array}{l}656883- \\
3874124\end{array}$ & (kirjanova,1951) siddiqi, 1976 & $\begin{array}{l}\text { Mojtahedi et al., } \\
1983\end{array}$ \\
\hline 8 & Meloidogyne javanica & Feiz Abad city & $\begin{array}{r}665010- \\
3878142\end{array}$ & (Treub, 1885) Chitwood, 1949 & Kheiri, 1972 \\
\hline 9 & Nagelus leptus & $\begin{array}{l}\text { Rokn Abad } \\
\text { village }\end{array}$ & $\begin{array}{l}593414- \\
3891102\end{array}$ & (Allen, 1955) Siddiqi, 1979 & $\begin{array}{l}\text { Mojtahedi et al., } \\
1983\end{array}$ \\
\hline 10 & Pratylenchus coffeae & $\begin{array}{l}\text { Shams Abad } \\
\text { village }\end{array}$ & $\begin{array}{l}642708- \\
3875236\end{array}$ & $\begin{array}{l}\text { (zimmermann, 1898) filipjev and } \\
\text { Schuurmans Stekhoven, } 1941\end{array}$ & Kheiri, 1972 \\
\hline 11 & $\begin{array}{l}\text { Pratylenchus } \\
\text { neglectus }\end{array}$ & $\begin{array}{l}\text { Shams Abad } \\
\text { village }\end{array}$ & $\begin{array}{l}642006- \\
3878430\end{array}$ & $\begin{array}{l}\text { (Rensch, 1924) Filipjev, Schurmans } \\
\text { Stekhoven, } 1941\end{array}$ & Kheiri, 1972 \\
\hline 12 & $\begin{array}{l}\text { Pratylenchus } \\
\text { wescolagricus }\end{array}$ & $\begin{array}{l}\text { Dogh Abad } \\
\text { village }\end{array}$ & $\begin{array}{l}665031- \\
3878144\end{array}$ & Corbet, 1983 & Alvani et al., 2016 \\
\hline 13 & Psilenchus aestuarius & Feiz Abad City & $\begin{array}{l}665031- \\
3878147\end{array}$ & Andrassy, 1962 & $\begin{array}{l}\text { Mokarram Hesar } \\
\text { et al., } 2010\end{array}$ \\
\hline 14 & $\begin{array}{l}\text { Psilenchus } \\
\text { curcumerus }\end{array}$ & $\begin{array}{l}\text { Bardaskan } \\
\quad \text { City }\end{array}$ & $\begin{array}{l}594560- \\
3890373\end{array}$ & Rahaman Ahmad and Jairajpuri, 1994 & - \\
\hline 15 & Psilenchus iranicus & $\begin{array}{l}\text { Rokn Abad } \\
\text { village }\end{array}$ & $\begin{array}{l}593414- \\
3891102\end{array}$ & Kheiri, 1970 & Kheiri, 1970 \\
\hline 16 & Psilenchus hilarus & $\begin{array}{l}\text { Shams Abad } \\
\text { village }\end{array}$ & $\begin{array}{l}642024- \\
3878403\end{array}$ & Siddiqi,1963 & $\begin{array}{l}\text { Ebrahimi et al., } \\
2003\end{array}$ \\
\hline
\end{tabular}
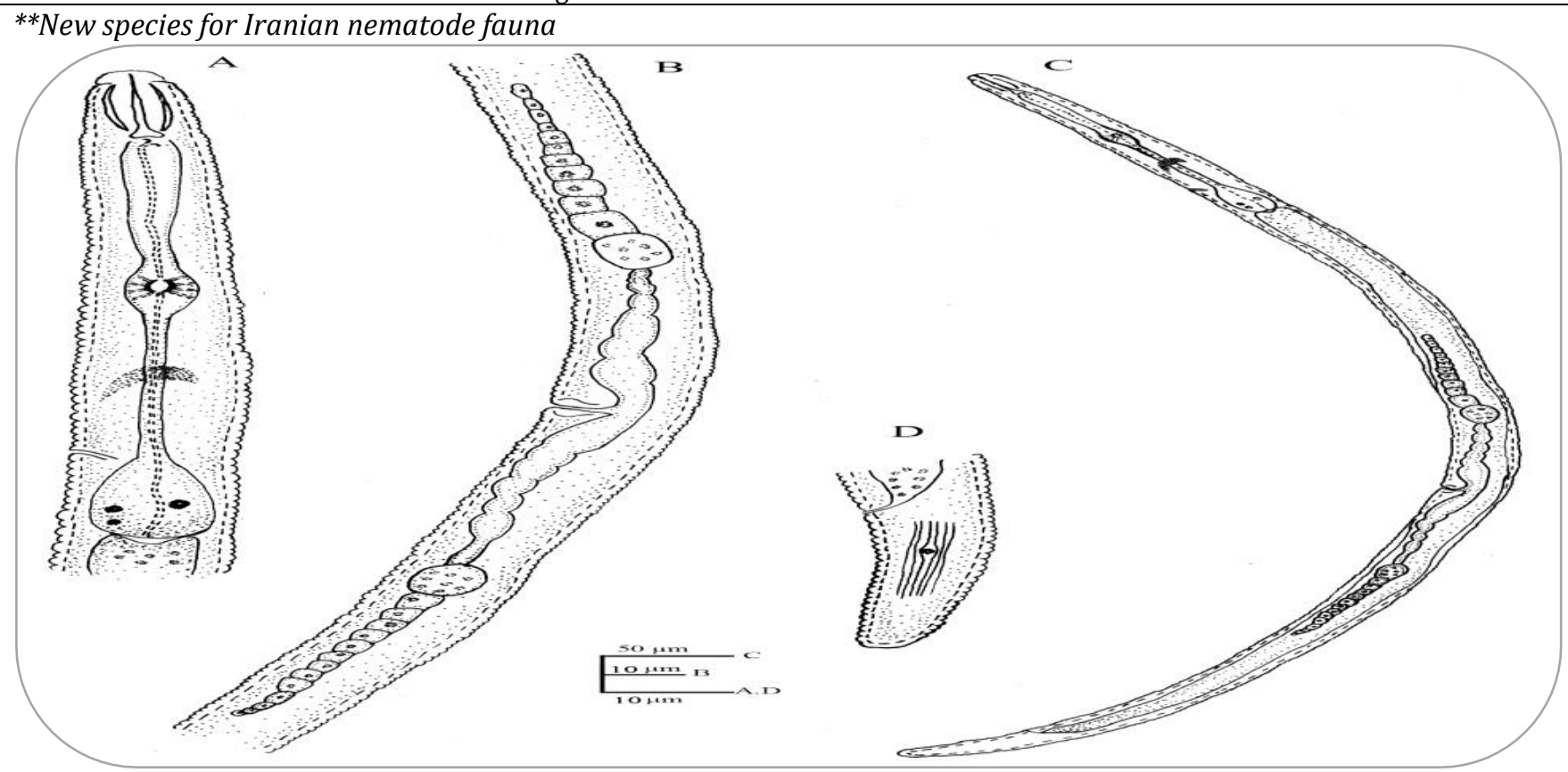

Figure 1. Merlinius gatevi, A: Head region with oesophagus; B: Ovary; C: whole of body; D: Tail of female 
Body annuli fine, about $1.6 \pm 0.1$ (1.5-1.8) $\mu \mathrm{m}$ wide. Lateral fields with 6 lines. Head separated from body outline, height $5 \mu \mathrm{m}$ and width $8 \mu \mathrm{m}$; moderately sclerotized; with 6 annuli. Spear knobs slightly downwards, height $3 \mu \mathrm{m}$, width $5 \mu \mathrm{m}$. Cardia rounded to semi oval. Spermatheca rounded to oval. Vaginal walls moderately sclerotized. Sub-cylindrical tail with rounded and non-annulated terminus. Tail annuli at the ventral side 21-24. Phasmids situated in the frontal half of the tail.

Table 2. Morphometric characters of the Iranian population of Geocenamus Koreanus and Merlinius gatevi and comparison with original descriptions (Measurements are in $\mu \mathrm{m}$ ).

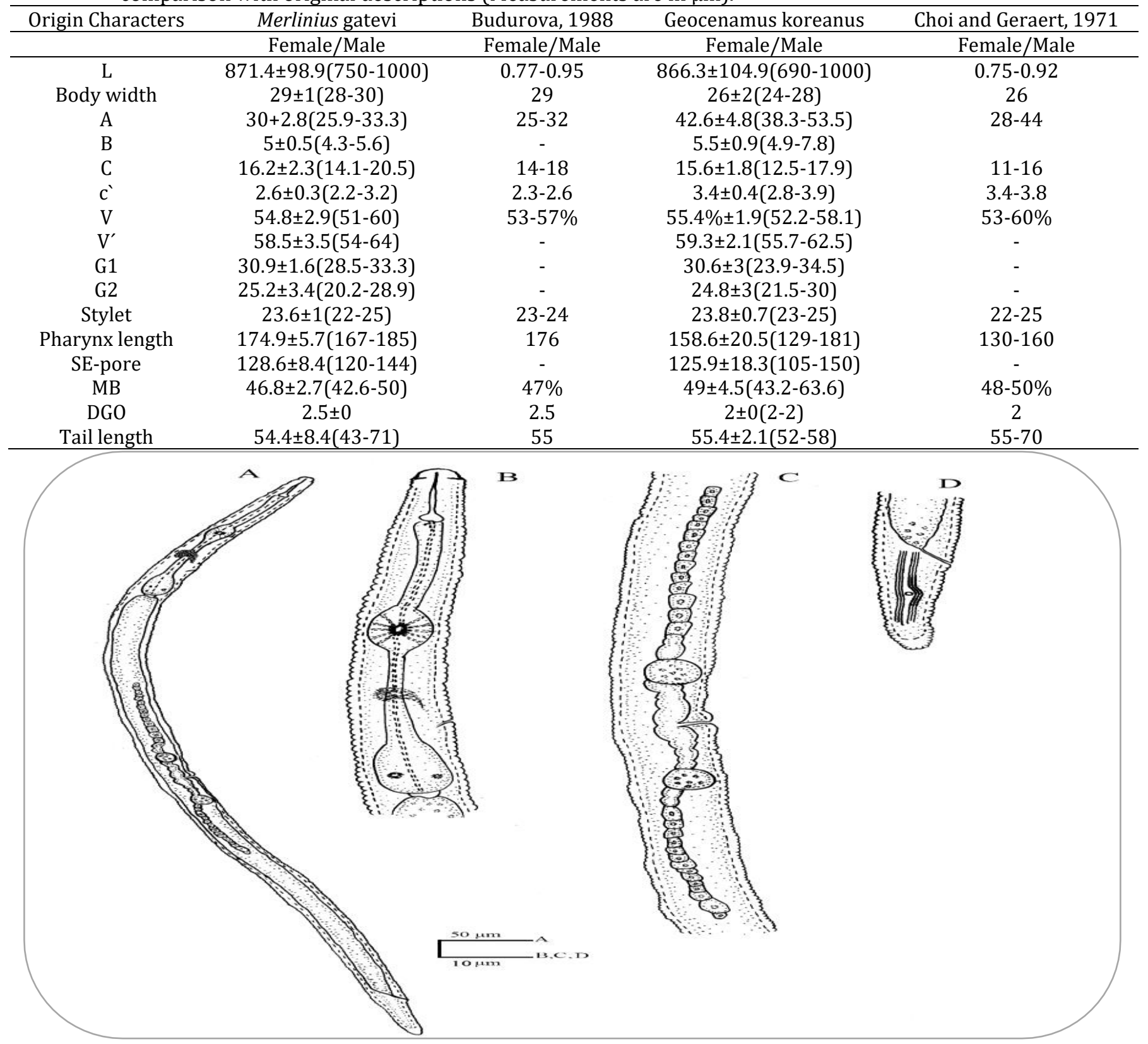

Figure 2. Geocenamus koreanus, A: whole of body; B: Head region with oesophagus; C: Ovary; D: Tail of female
Male: not founded.

This species is distinguished by the number of tail rings compared to the close species same Geocenamus dobroticus and Geocenamus tenuidens. In this species, the number of tail rings was 21-24 but in Geocenamus dobroticus 27-30 and in Geocenamus tenuidens 45-80. This is the first report of this species from Iranian nematode fauna.

Geocenamus koreanus (Choi and Geraert, 1971) (Figure 2, Table 2)

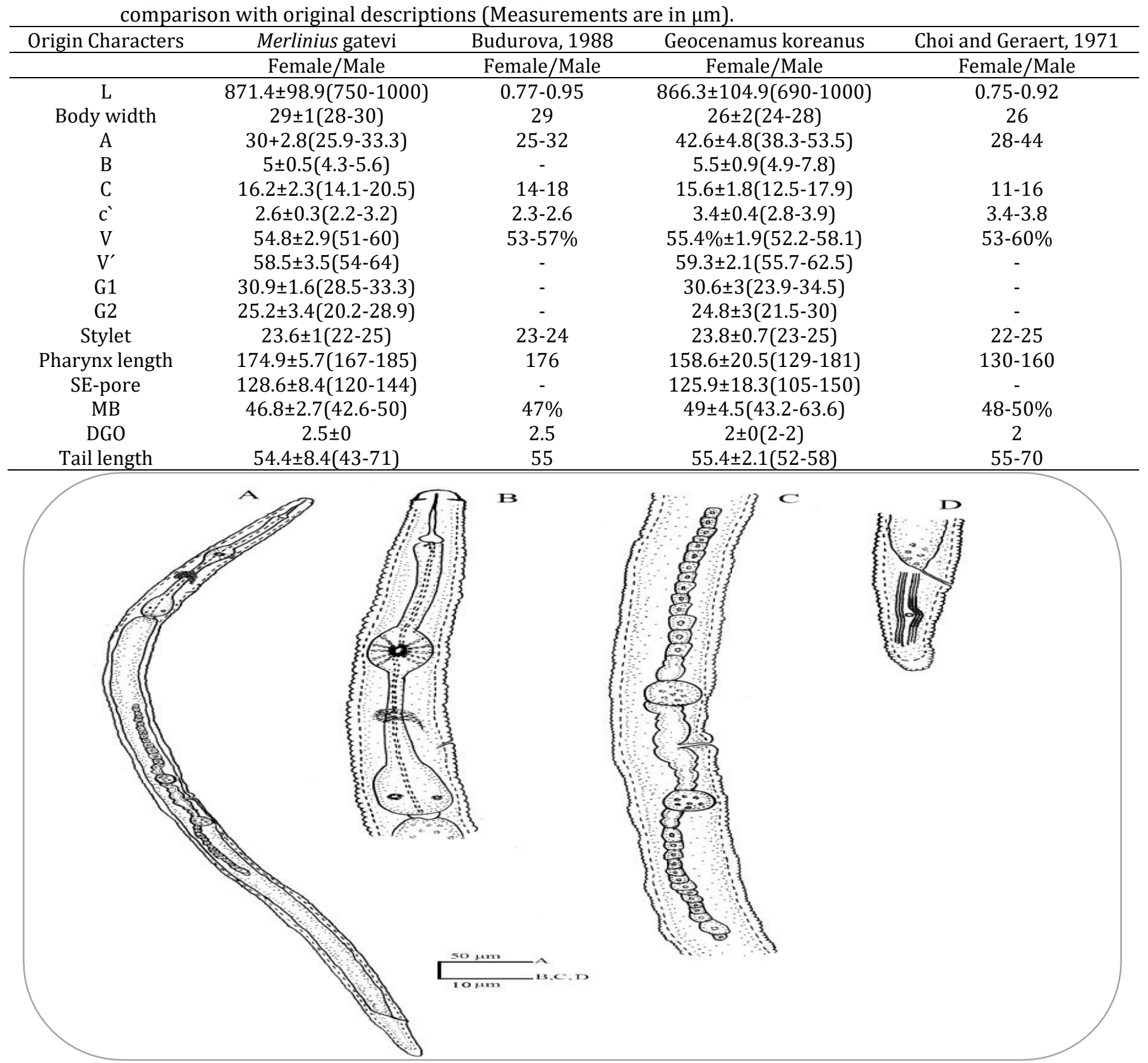


Body straight or slightly curved ventrally. Longitudinal striations on body prominent, 7-8 dorsal, 8-9 central; longitudinal striate are formed by involutions of the coarse transverse striations $1.6-2 \mu \mathrm{m}$ wide. The lateral field is prominent, occupying $1 / 4$ th of the body width and with 8 incisures visible in cross-sections (the outer 2 lines, however, not visible from a lateral view). Head slightly offset, with 5-6 annuli; cephalic framework slightly sclerotized, situated 2-3 head annuli anteriorly than the level of the head-constriction; head divided longitudinally into 5-6 sectors corresponding. Conical part of style cery fone and delicate, measuring about $60 \%$ of the spear length, and surrounded by a guiding apparatus consisting of a tubular and an oval part; stylet knobs well developed and flattened anteriorly. Median bulb oval. Terminal bulb cylindrical. Excretory pore opposite anterior end of terminal bulb. Vulva not than 4$4.2 \mu \mathrm{m}$ wide and provided with anterior and posterior epiptygma. Spermathecae rounded, filled with sperm. Tail sub-cylindrical, slightly tapering towards the rounded, coarsely annulated tip. Plasmids at about 1 and diamerer posterior to the anus (17.5-32\% of tail length).

This species was compared with close species Geocenamus hexincisus. Studied species was similar to the close species number of longitudinal grooves on the surface of the body, but differ in style and tail length, so that the length of stylet in studied species was more than Geocenamus hexincisus (The length of the stylet in the discussed species is $22-25$ and in the similar species is 19-19 $\mu \mathrm{m})$. In addition, the length of tail and factor $\mathrm{C}$ differ in these species. C Factor is 11-16 in studied species and 18-23 in the close species. Therefore, population under study was identified as Geocenamus koreanus.

\section{CONCLUSION}

In this study, the fauna of plant parasite nematodes in pistachio root rhizosphere of Khorasan Razavi province, Iran, were investigated and 19 species belonging to 8 genera were identified. During this study, two nematode species Geocenamus koreanus and Merlinius gatevi were described for the first time from Iran nematode fauna.

\section{REFERENCES}

Allen, M. W. 1955. A review of the nematode genus Tylenchorhynchus. Univiversity of California Publications in Zoology, 61: 129-166.

Alvani, S., E. Mahdikhani-Moghadam, H. Rouhani and A. Mohammadi. 2016. A checklist of the family Pratylenchidae Thorne, 1949 from Iran. Zootaxa,
4079: 179-204.

Amuzegar, J. 2003. Iran's theocracy under siege. Middle East Policy, 10: 135.

Andrássy, I. 1959. Nematoden aus dem Psammon des AdigeFlusses, I. Memorie del Museo Civico di Storia Naturale di Verona, 7: 163-181.

Baadl, S., E. Mahdikhani Moghadam and H. Rouhani. 2012. Species of Two Genus Geocenamus and Merlinius of Rapeseed Fields in North Khorasan Province. Journal of Plant Protection, 26: 269-277.

Brzeski, M. 1991. Taxonomy of Geocenamus Thorne \& Malek, 1968 (Nematoda: Belonolaimidae). Nematologica, 37: 125-173.

Budurova, L. 1988. Three new nematod species (Nematoda, Tylenchida) from Bulgaria. Acta zoologica bulgarica: 43-48.

Chitwood, B. 1949. 'Root-knot nematodes'. Part 1. A revision of the genus Meloidogyne Goeldi, 1887. Proceedings of the Helminthological Society of Washington, 16: 90114.

Choi, Y. and E. Geraert. 1971. Two new species of Tylenchida from Korea with a list of other nematodes new for this country. Nematologica, 17: 93-106.

Corbett, D. 1983. Three new species of Pratylenchus with a redescription of $P$. andinus Lordello, Zamith \& Boock, 1961 (Nematoda: Pratylenchidae). Nematologica, 29: 390-403.

De Grisse, A. T. 1969. Redescription ou modifications de quelques technique utilis [a] es dan l'etude des $\mathrm{n}$ [a] ematodes phytoparasitaires, 34: 351-369

Ebrahimi, N., Kheiri, A. and Pakniat, M. 2003. Introduce seven plant parasite nematode species Tylenchida for Iran. 15th Iranian plant protection congress, 2: 310.

Filipjev, I.N. and Schurmans Stekhoven, J.N. 1941. A manual of agricultural helminthology. Leiden, Netherland. Brill Publishers, 878.

Geraert, E. 2008. The Tylenchidae of the world: identification of the family Tylenchidae (Nematoda). Academia Press. Pp. 139.

Goodey, J. B. 1952. Tylenchorhynchus tessellatus n. sp.(Nematoda: Tylenchida). Journal of Helminthology, 26: 87-90.

Huang, C. S. and D. J. Raski. 1987. New records of Paratylenchus Micoletzky, 1922 from Brazil with descriptions of two new species (Tylenchulidae: Nemata). Journal of Nematology, 19: 69.

Jabari, H. and G. R. Niknam. 2008. Plant parasitic nematodes of vegetable fields in Tabriz area. 
Jenkins, W. 1964. A rapid centrifugal-flotation technique for separating nematodes from soil. Plant disease reporter, 48: 692.

Kheiri, A. 1970. Two new species in the family Tylenchidae (Nematoda) from Iran, with a key to Psilenchus de Man, 1921. Nematologica, 16: 359-368.

Kheiri, A. 1972. Plant parasitic nematodes (Tylenchida) from Iran. Biologisch Jaarboek Dodonaea, 40: 224-239.

Kirjanova, E.S. 1951. Soil nematodes found in cotton fields and in virgin soil of Golodnaya Steppe (Uzbekistan). Trudy Zoologicheskogo Instituta Akademiya Nauk USSR, 9: 625-657.

Mojtahedi, H., G. Balali, A. Akhiani, S. Barooti and A. Naderi. 1983. Tylenchorhynchid nematodes of Iran (Tylenchoidea, Nematoda). Plant protection congress of Iran. 7.

Mokaram-Hesar, A., E. Mahdikhani-Moghadam, J. Perira, M. Mundo-Ocampo and J. Baldwin. 2010. Different population of Psilenchus spp. Iran with introduction of a new species of the genus. In: Proceedings of 19th Iranian Plant Protection Congress.

Nakhaee Nejad, M. 2007. The first pistachio processing and packaging conference at Ferdowsi University of Mashhad.

Neshat, S., F. Khozeini, S. BAROUTI and S. Rezaee. 2011. Plant parasitic nematode fauna in pistachio orchards from Sirjan. Journal of Research in Plant Pathology, 1: 25-32.

Rahaman, P. F., I. Ahmad and M. Jairajpuri. 1994. One new and two known species of the family Tylenchidae. Indian Journal of Nematology, 24: 62-68.

Raski, D. 1975. Revision of the genus Paratylenchus Micoletzky, 1922 and descriptions of new species. Part II of three parts. Journal of Nematology, 7: 274.

Rensch, B. 1942. Aphelenchus neglectus sp. n. eine neue parasitare Nematodenart. Zool. Anz., 59: 277-280.

Schoevers, T. 1941. A manual of agricultural helminthology. Tijdschrift Over Plantenziekten, 47: 234-236.

Sher, S. 1966. Revision of the Hoplolaiminae (Nematoda) VI. Helicotylenchus Steiner, 1945 1. Nematologica, 12: 156.

Siddiqi, M. 1979. Taxonomy of the plant nematode subfamily
Merliniinae Siddiqi, 1970, with descriptions of Merlinius processus n. sp., M. loofi n. sp. and Amplimerlinius globigerus n. sp. from Europe. Systematic Parasitology, 1: 43-59.

Siddiqi, M. 2000. Order Tylenchida. Tylenchida: parasites of plants and insects: 86-121.

Siddiqi, M. R. 1976. New plant nematode genera Plesiodorus (Dolichodorinae), Meiodorus (Meiodorinae subfam. n.), Amplimerlinius (Merliniinae) and Gracilancea (Tylodoridae grad. n.). Nematologica, 22: 390-416.

Siddiqi, M. R., D. J. Hooper and E. Khan. 1963. A new nematode genus Paralongidorus (Nematoda: Dorylaimoidea) with descriptions of two new species and observations on Paralongidorus citri (Siddiqi 1959) n. comb. Nematologica, 9: 7-14.

Sturhan, D. 2012. Contribution to a revision of the family Merliniidae Ryss, 1998, with proposal of Pratylenchoidinae subfam. n., Paramerlinius gen. n., Macrotylenchus gen. $n$. and description of $M$. hylophilus sp. n.(Tylenchida). Journal of Nematode Morphology and Systematics, 15: 127-147.

Tavallali, V. and M. Rahemi. 2007. Effects of rootstock on nutrient acquisition by leaf, kernel and quality of pistachio (Pistacia vera L.). American-Eurasian Journal of Agricultural and Environmental Science, 2: 240246.

Thorne, G. and R. B. Malek. 1968. Nematodes of the Northern Great Plains: Part 1 Tylenchida [Nemata Secernentra] Technical Bulletin South Dakota Agricultural Experiment Station, 31: 1-111.

Treub, M. 1885. Onderzoekingen over sereh-ziek suikerriet gedaan in's Lands Plantentuin te Buitenzorg. Landsdrukkerij. Batavia, 2: 1-39.

Wasilewska, L. 1965. Ditylenchus medicaginìs sp. n., a new parasitic nematode from Poland (Nematoda, Tylenchidae). Bulletin de l'Academie polonaise des Sciences. Classe II. Serie des Sciences Biologiques, 13: 167-170.

Zimmermann, A. 1898. De nematoden der koffiewortels. Kolff. 1: 10-50.

\begin{tabular}{lll}
\hline Contribution of Authors: & & \\
Reyhane Hadadfar & $:$ & Write original manuscript and conduct research \\
Esmat M. Moghadam & $:$ Help in writing manuscript \\
Sareh Baghaee & $:$ Data analysis \\
Majid S. Bajestani & $:$ Review manuscript \\
\hline
\end{tabular}

